\title{
A FEW MARRIAGE SONGS OF THE PARSEES AT NARGOL, PART II. $\dagger$
}

This is the fourth of my papers, 1 in which $I$ have been Introduction. speaking of some Parsee songs. My previous papers are the following :-1. "The Marriage Customs among the Parsees 2" in which I have given the translation of $10^{1}$ Parsee Marriage songs. 2. Parsee Life in Parsee Songs. Cradle Songs. ${ }^{3}$ 3. A Few Marriage Songs of the Parsees at Nargol.4 This day I propose to speak for the second time on some Parsee Marriage Songs, sung at the Parsee town of Nargol. But, before I do so, I will at first say a few words on the subject of Marriage Songs in general.

Songs are prevalent among all kinds of people whether Songs. savage or civilized. There are songs of pleasure and songs of sorrow. Songs sung on occasions of pleasure give a kind of amusement; those sung on occasions of grief give consolation. So, both give

† Read before the Anthropological Society of Bombay on Journal p. 6.

1 They are the following:-(a) Bridegroom's Betrothal.

(b) A brother sending presents to a sister on the occasion of her children's marriage.

(c) Song, sung just before the marriage.

(d) Song, of a mother-in-law welcoming her son-in-law.

(e) Song, sung when the wedding presents are carried.

(f) Song, sung when the bridegroom leaves for the bride's house.

(g) Song, sung when a mother-in-law welcomes her son-in-law at the time of marriage.

(h) Song, sung at the close of the marriage.

(i) Song, sung when bidding farewell to the bride at the time of her going to the house of the bridegroom.

j) Song, sung when the bridegroom takes the bride to his house.

2 Journal of the Anthropological Society of Bombay, Vol. V, pp. 242 282 Vide my "Marriage Customs among the Parsees."

I Ibid Vol. V, pp. 427-43. (Vide my Anthropological Papers, Part I, pp. $140-157$.

4 Ibid Vol. XIII, pp. 629-638. 
a kind of delight. We have devotional religious songs, panegyrieal songs, satirical songs, marriage songs, funeral songs, etc. Such songs need not necessarily be composed by great literary men. They are, at times, composed even by illiterate persons. They are intended to give vent to feelings and passions working in the breast of men. Among all the songs of various kinds, those sung on marriage occasions play a prominent part in the social life of a people. In fact, they give us a glimpse into the social life of the people. They are sung on marriage occasions only. A Parsee Gujarati proverb says :- "લગનના ગીત લગનપર જે સોભે," i.e., "The Marriage Songs seem best only on Marriage occasion."

Among the ancient Greeks, a marriage-song was spoken of as Epithalamium or Epithalamy from epi "a Epithalamiums or song ", and thalmos "a bridal chamber, a Marriage Songs.

bridal bed, a marriage." It was so called, be cause, among them, the best marriage songs were those sung by boys and girls at the bed-chamber, just before the couple retired to their bed chamber and in the early morning, just before they came out of their bed chamber. These songs 1 " consisted of invocations of blessings and predictions of happiness, interrupted from time to time by the ancient chorus Hymen Hymenæ."'2 Among the Romans, the marriage songs were mostly sung by girls alone after the departure of the marriage guests. They " contained much more of what modern morality would condemn as obscene."'3 Among some of the well-known epithalamiums are those of Zoroaster and Solomon

1 Encyclopædia Britannica, 9th edition, Vol. 8, page 496.

2 Hymen was supposed to be the son of Bacchus and Venus, or, according to others, of Apollo and one of the Muses. Having fallen in love with a girl, he followed her in the disguise of a woman, and, having once saved the girl and her party from the hands of pirates, was able to secure her love and her hand. H s was a very happy married life, and so, he was often invoked in marriage blessings and songs. Another version of his story represents him as a very unfortunate man having died on his marriage day, and so, he is supposed to have been propitiated on marriage occasions to escape ill-luck.

3 Ibid. 
among the ancients, and that of the poet Spenser among the moderns.

The song of Solomon, spoken of, at times, as 'Canticle ' (from canare to sing) or the "song of songs" and Solomon's Marri- which forms the $22 \mathrm{nd}$ book of the old Tes-
age Song.

tament, is taken to be an epithalamium or marriage song. There is a great difference of views among scholars about the function of this book. Some deny the canonicity of this book on the ground, that a religious book, like the old Testarnent, cannot contain a book which speaks of physical love and marriage and which is a kind of amatory poem. ${ }^{1}$ This objection or doubt has been explained away by some, that it is "an allegory indicating the love of Jehovah to his chosen people." The Christians adopted the allegorical view and maintained that it symbolized the love of Christ for his Church. This reminds us of the poems of Hafiz, known as the Diwan-i Hafiz, where also Hafiz's praise of wine and wife is taken to be allegorical. In the song of Solomon, the author, now and then, appeals to womankind of Jerusalem in general as " 0 daughter of Jerusalem " (Chapter I, 5 ; II, 7 ; III, 5 ; V, 8 ; VIII, 4.)

It seems, that the ancient Iranians also had their marriage songs. The country, whose later national Zoroaster's Marri- poet, Firdousi, often speaks of songsters and
age-Song. songstresses (râmashgar), cannot be without its marriage songs. The 53rd Chapter of the Gathas is taken as a marriage song of Iran's prophet Zoroaster, composed by him for the marriage of his daughter Pouruchishti. His song is addressed to his marrying daughter (tu Pouruchista, i.e., Thou Pouruchista!) ${ }^{2}$ to the marrying brides (vazyamnabyo ${ }^{3}$ kainibyo) and bridegrooms (khshmaibyacha vademno) ${ }^{4}$ (you bridegrooms) ${ }^{5}$

1 Vide Beeton's Dictionary of Ancient Art and Literature, Vol. 1 p. 428. 
and to all men and women (narô athá zenyô). ${ }^{1}$ Dr. Mills speaks of this as " a marriage song, but one of a politically religious character". 2

Edmund Spenser, the well-known English poet of the 16th Spenser's Epitha- century, has written a poem entitled 'Epilamion. thalamion." It is taken to be a marriage song for his own marriage in November, 1594.

These epithalamiums, though specially celebrating, or refer-

Appeal to Womanhood in general in these Epithalamiums. ring to, some particular marriages, make a general appeal to womanhood. We saw above that Zoroaster appealed to all marrying brides and bridegrooms, to all men and women. Solomon appeals to all "daughters of Jerusalem." So, Spenser appeals to "Ye learned sisters." In the very beginning, he says,

"Ye learned sisters, which have oftentimes

Beene to me ayding, others to adorne,<smiles>[13CH3][13CH3]</smiles>

Now lay those sorrowful complaints aside ;

And, having all your heads with girlands crownd,

Helpe me mine owne loves prayses to resound."3

This appeal to "Ye learned sisters" reminds us of a similar appeal to sing "to mothers and ladies" in a recent Parsee

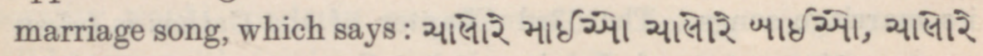
ગીટડાં ગાયજ, $\ldots \ldots \ldots \ldots 4$ मનનનાં શુભ લગનનાં ચાલાર ગીટડi गાयूg. i.e., "Come on O Mothers ! Come on O Ladies! Let us sing the songs. Let us sing the songs of the auspicious marriage of.....4

1 Ibid. 6.

2 Mill's Gathas, S. B. E. Vol. XXXI, p. 187.

3 Epithalamion, lines 1.14, p. 587. The Globe Edition of the Complete Works of Edmund Spenser, by R. Morris, with a Memoir by J. W. Hales (1873).

4 Here the name of the bride is mentioned in the song. 
These Epithalamiums show that their composers have intended them, not only for the ears of the then brides and bridegrooms, but also for the ears of all future brides and bridegrooms, for the ears of all who attend the marriage gatherings. They were to hear them, understand them and take lessons from them.

Spenser's Epithalamion treats of "various matters of the

Various matters referred to in the Epithalamiums. marriage day - of his love's waking, of the merry music of the minstrels, of her coming forth in all the pride of her visible loveliness, .... of her standing before the altar........, of the bringing her home, of the rising of the evening star, and the fair face of the moon looking down on his bliss not unfavourably." 1 In Parsee marriage songs, we see a similar variety. They begin singing about marriage events prior to the marriage day. They begin, for example, with a day long previous to the marriage day - at times a fortnight or a month before the marriage day-when the ladies of the family begin pounding the $\operatorname{adad}^{2}$ ( 24२s ) for the pâpat ${ }^{3}$ ( Чા૫S )

In the first two marriage songs of Nargol described in my previous paper, we saw, that the songs referred to occasions before the marriage, occasions when the house lady began the marriage preparations. In this paper, I give two more songs.

-This song is spoken of in Gujarati as that of murat ( भુર્ત 4)

Mâdavsarâ Song. i.e., the fit time, the auspicious moment or season. The Gujarati heading of the song speaks of it as મુરત ભેર રેાપતી વ

1 Ibid pp. XLIX-L.

2 અર૩, અદડ, " a kind of Vetch (Dalichos Pilesus), a kind of pulse" (Belsare's Dietionary).

3 "A thin crisp cake made of flour with spices, a sort of wafer-cake" (Gujarati and English Dictionary of Shapurji Edulji, 1863) page 503.

4 Sans. मुहूर्त 'a period, time (auspicious or otherwise). The period is generally that of the $1 / 30$ th part of a day of 24 hours; so it comes to 48 minutes." 
to be sung at the auspicious time of planting the bêr. ${ }^{1}$ On this occasion, the branch of a tree is planted. The tree on the Bombay side is generally a mango-tree. In Bombay, the occasion is spoken of by the Parsees as Mâdavsarô ( भાંડવસરે।) i.e., the erection of a pavilion (mâdav, Sans. मंडप) ${ }^{2}$

I had the pleasure of seeing this ceremony of planting a branch at Naosari, on the occasion of the marriage of a relative. ${ }^{3}$ The ceremony is as follows: A post is put up in a pit in the ground near the house of the bride or bridegroom, generally on the right hand side of the house while entering. Betel-leaves, betelnuts, dry date, curd, ghee or clarified butter, a sugar cake ( અતાસે ), a silver coin, and a copper coin are first put into the pit. Generally some principal male members and four principal female members, none of whom should be a widow, touch the post when it is lowered into the ground. If there is no sufficient place for all the eight persons to touch the post, one or two may touch the post and the others may touch with their hands the body or bodies of a person or persons in the front. The post, before being put into the ground, is decorated with kunku, kharaftu and some leaves of plants like âsâ-pâlô. The family priest recites an Ahunavar or Yatha Ahu Vairyo. 4 On the completion of this ceremony of putting in the post, which

1 The word may be another form of બીલ "a leaf of a tree sacred to Shiva". Or, it may be Persian bed بيد willow, rattan.

2 The second part of the word may be Persian $\mathcal{G}^{\prime}$ warâi, i.e., house, because the pavilion becomes for the time being, a kind of house.

3 On 12th May 1918, on the marriage of Mr. Ardeshir Kekobad Modi, at present, the Agent and Managing Director of the Naosari Electric Supply Company, Limited.

4 For this prayer-formula, vide my "Religious Ceremonies and Customs of the Parsees "pp. 341-348. The Pahlavi Shayast la-Shayast enjoins the recital of the Ahunavar when one goes to desire a wife (mun val nishman bavîhûnastan vazlûnêt; Dr. M. B. Davar's Text p. 99. S.B.E., Vol. V p. 392). The Rivâyets also speak of this recital on marriage occasions (vide M. R. Unwalla's Rivayat of Darab Hormuzdyar with my In-

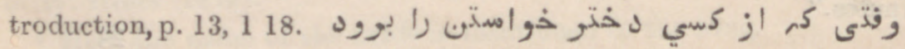


is, as it were, the foundation-laying ceremony for the pavilion, the pit is filled up and incense is burned over fire which is produced there on a vase. The lady guests are then presented with sugar-cakes (batâsâ) and the male guests with flowers and cocoanuts. In some Parsee villages, the post is not of dry wood, but of a green branch of a tree. Even when a wooden post is put in, a fresh branch or a cluster of fresh leaves of a tree, are attached to the post. A Gujarati document of 1631 A.c. mentions the fee of the priest who officiated at such marriage murat ceremony as Re. 1.1

In many a case, though the necessity of the observance of a peculiar custom ceases, people stick to the custom in a lesser or abbreviated or symbolic form. We find an instance of this in our present case. Formerly, in Parsee villages, the people generally celebrated all the marriage festivities near their houses and in their own streets. So, a pavilion and the above accompanying ceremonies or customs for laying the foundation of the pavilion were necessary. Now-a-days, public places, like the All-bless Bag in Bombay, are provided for all marriage celebrations. But still, some people, though they do not erect a pavilion, perform this mandap-planting ceremony.

The following song is sung at Nargol on this occasion. I give the text as received by me from Nargol.

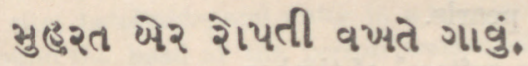

1 માહરે સુનાનાં ધારણુ રેપીઆંરે, માહરે ३ પઇ્યાના જડેઆ વલોટ માડવડેเ મેતીઓ રચીઓ રે.

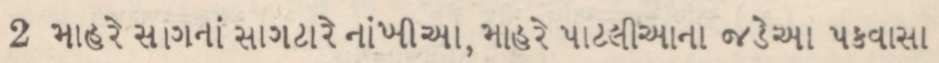
भાડવડેા મેતીએ ર્ચીઓર.

1 For this fee and other payments to priests on various social and domestic occasions, vide my Article on "the Parsis," in Mr. R. E. Enthoven's "Tribes and Castes of Bombay", Vol. III, p 213. 


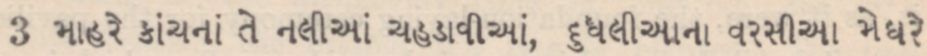
માડવડે। મોતીએ ર્ચીઓરે.

4 માહરે કુંકાંના કારા નાંખેઆરે, દહી થરે ચ આ આ પીંડાર માડવડે। મેતીએ ર્ચીઓરે.

5 કાચી તે ઈ્ટેનાં આંગણુંર, ઓસરીઓ ઠાલેઆ કાચરે માડવડેં મેતીચ્ચ રચીઓરે.

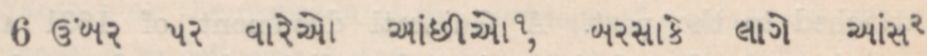
भાડવડે। મોતીએ ર્ચીઓરે.

7 માહરે ખ૩કાઓ મેતીના સાતીઆર, ઉભે પાટે વારેઆ પાટ, માડવડેા મેતીીએ રચીઓરે.

8 भાહરા કેણછ આવેઆરે, કેણુળ આવસેરે-માહરા કેણુછની નેવું રે લાગીવાટ-છેડા રે ધુંटी પાઘડીરે.

9 માહરા (ઘેર ધણુ) છ આવેઆરે, (ભાઈ અથવા સગો) છ આવસેરે, ( ત્રીનેન ભાઈ અથવા સગે।) છની નેવું રે લાગીવાટ, छેડા રે ધુરી પાઘડીરે:-

( વીન રીતે આગલ ખીળ્⿰ નામે હેલ તે લેવાં)

Song No, 3.

Translation.

1. I have planted golden props 4 .

I have put up silver ropes. ( પલેટ ) ${ }^{5}$.

I have decorated the pavilion ${ }^{6}$ (or the bower or arbour) with pearls.

2. I put up rafters ${ }^{7}$ of timber.

I fixed lathes of planks. 8

I have decorated the pavilion with pearls.

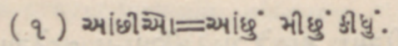

( ૨ ) આ્સ= =ર૨૫ટા.

( ૩ ) सાતી આા=ચે|ई.

4 ધારણ "a prop or support of a house".

5 વલ़ı. I think the word is the same as વરેાત "a large rope."

๑ માં૩9, મં૩૫, an open building ; a bower.

7 सાકત rafters.

3 Another form of чเટલі, a plank. 
3. I put up glass tiles over it.

- There rained the rain of milk.

I have decorated the pavilion with pearls.

4. I put up the mixture for plaster $^{1}$ with turmeric powder.

I put up the layers ${ }^{2}$ with curdle.

I decorated the pavilion with pearls.

5. The court-yards are (made) of raw bricks.

Steps are (made) of glass (or crystal).

I have decorated the pavilion with pearls.

6. I performed the achoo minchu ( ${ }^{3}$ (धुं भीछुं) on the threshold.

On the door-frame ${ }^{4}$ are put up the besmearing marks 5 . My pavilion is decorated with pearls.

1 ગારા or ગાર (cf. ચુનાનેા ગાર) a mixture to be used as mortar or plaster.

2 પโડิเર It seems to be another form of પીડૅ " a kind of white earth used to cover the walls of houses."

3 અાધું, भીફું " a ceremony performed on the occasion of admitting the bride and the bridegroom into his or her house, on the day of betrothal, marriage, or any other occasion " (Gujarati-English Dictionary by Now rojee Furdoonjee). Here, the word is not explained. Other Gujarati Dictionaries do not give the word. I venture to derive the word as follows: અાધु" is "little", another form of ચાધુ. भीધુ is from Sans, मिच्छ, to hinder, obstruct, annoy. So साधुं भीधुं is the ceremony which symbolizes or signifies "the lessening or removing the hindrances or obstructions in married life ". In this ceremony, the lady, who welcomes, at the threshold of the house, the bride or the bridegroom on marriage occasions or a child or adult on any other joyful occasion, places a few grains of rice, betel-nuts, and water in a tray, and passing the tray three times round the head of the person welcomed, throws the articles on the ground near his feet, to signify that all evil or misfortunes in life, if any, may pass off.

\ બારસાઝ or બારસાખ, a door-frame.

5 આ્યા. In the copy of the marriage song supplied to me, the word આંસ is explained in a foot-note as ખર૫દું i.e. the besmearing marks on the door-frame. On many occasions, the door-frames are besmeared with turmeric powder and another red powder known as kunkun $\left(f^{*} \jmath^{\prime}\right)$ कुकू " a powder prepared from turmeric coloured with lemon juice. alum etc., for marking the forehead." (Nowrojee Furdoonjee's GujaratiEnglish Dictionary). In this case, the word ચ્મા may be Sans. आस, a seat. The besmearing or decorating marks are made with four fingers and ar in the form of simple, seats, one over another. 
7. In the first front room of my house ${ }^{1}$, there are auspicious marks ${ }^{2}$ made of pearls (i.e, pearl powder).

There seats ${ }^{3}$ are arranged in a proper sitting ${ }^{4}$ position. My pavilion is decorated with pearls.

8. My "so and so ${ }^{5}$ has come. My "so and so" will come. I am waiting for my "so and so." Skirts and turbans ${ }^{6}$ are coming in a loose line. ${ }^{7}$

9. My so and so ${ }^{18}$ has come ; my so and so ${ }^{18}$ will come; I am waiting for so and so. ${ }^{8}$

I Khadaki ( first front room next to the verandah.

2 સાતીચ્મા or સાથીગ્મા is "an auspicious mark or sign made or painted on doors, etc." Here, the reference is to the chok ચે|ई; vide my first paper on the Nargol Songs (Journal Anthropological Society of Bombay, Vol. XIII page 634. Vide my Anthropological papers Part IV, p. 140).

3 પાટ ( પાટલ્ર) a bench, or a form, a seat.

4 ઉल Чાટ i.e., in an erect position. The pats or patlas, when not used are put aside in an inverse or upside down ( $\sigma^{\circ}$ धा ) position.

5 ईैनश (konji) lit., who. The singer means "Mr. so and so."

6 The turbans are put on by various persons in various fashions. I do not understand what particular fashion is referred to. The last two couplets of the song seem to be a later addition by somebody, other than the original author, because all the seven preceding couplets ended with the repeated chorus-line માંડવરે મેતીર રચીચ્યારે, while this and the next couplet-the last two coulpets-have a different ending.

7 The signification is not clear. The word छुटl i.e., got loose is often used in an idiomatic way e.g., one speaks as માણુસાની હાર ધુટી i.e., " the row of men has got loose", meaning there is a long string of men coming one after another. Here the singer seems to say that guests with skirts (a kind of loose garment like pichodi પીછેાડી put on by Hindus in Gujarat across their shoulders) and turbans have begun coming. The word turban also is used figuratively for a male e.g., formerly one spoke as અઆન્ન ૧०० પાગડી હૂનર હતી i.e., "To-day there were present 100 turbans, meaning thereby that there were one hundred males present.

8 Here the names are recited. The meaning is well-nigh the same as that of the preceding couplet. It seems that, in the preceding couplet, the singer speaks of the house-lord and other relatives who are ready to receive the guests; and in this couplet, the singer speaks of some principal guests naming them individually. If there are a number of such guests, the lines of the song are repeated. 
The next song is that sung at the time of cleaning the wheat in winnowing fans. The song is spoken of as

The Song for the winnowing of wheat. that of holding the winnowing fans into the hand ( હાથ સुપડі ધર). One of the processes for the marriage celebration is to prepare flour, some days before the marriage, for the marriage feasts. The house-lady sings in the song that $(a)$ she went to the market and bought wheat, $(b)$ brought it to the house in carts, $(c)$ emptied the carts in the front of the house, $(d)$ cleaned the wheat in winnowing fans, $(e)$ collected it in round wicker baskets, $(f)$ then, taking it little by littre in trays, removed pebbles or dirt from it, $(g)$ collected the wheat, so cleaned, in earthen vessels, and then grinded it, while singing in the company of her neighbour friends.

The winnowing fans must be quite new. They are decorated with turmeric (હલદના અર૫૫ા).). Strings of flowers તેરગ are hanging at the two ends of the front side. They contain dry date, betel-nut, a turmeric piece (હલદને ગાંી piece of the kernel of a cocoanut. Four ladies hold in their hands the winnowing fans, and, while singing the song, winnow the above articles and exchange the fans from one's hands to another's. They exchange the winnowing fans five times.

The first part of the song is rather difficult to understand well. I give below this song sung during the winnowing of the wheat.

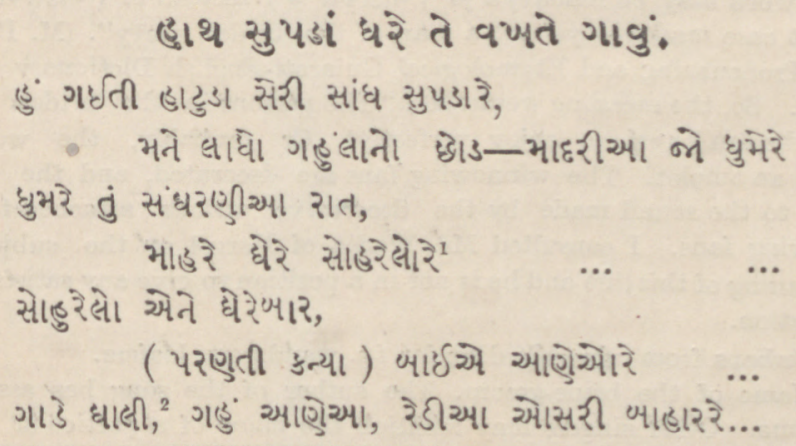




\section{સુપડ ગહું સોયાર સાંનસુવડારે, रेડીઆ टેપપાં भાહેरे \\ શાલીએ મુકી ધહું ચુંટીઆ \\ રેડીઆ भાટલાં भાહેरे \\ પડેસણુ માંડીગો ધંટાનો રાગ, મેં भાડીગ્ચા ધંટીના રાગ \\ પડેસસણે પાડી ભરકડીરે, મેં પાડી એે દેલા કણુકરે ...}

Translation.-I went to the market ${ }^{4}$ of the street ${ }^{5}$ for the purchase $^{B}$ of winnowing fans. I found 7 a plant of wheatlike 8 colour. There move ${ }^{9}$ the Madaryas. ${ }^{10}$

(2) You wander for the (whole) night, you wanderers. ${ }^{11}$ I have Sohrelo ${ }^{12}$ in my house. There move the Madaryas.

3 सิાયા=વહીર્મા

4 Hât ( હાટ) is a market. Hatdi ( small market.

5 Seri (સેરી), a lane, a street.

6 Sans. साध to complete, to recover, to make perfect. The word may be શેlધ, search; the idea seems to be of purchasing.

7 લાધધુ "to load," "to be found," "to accrue."

8 ગહુલે।" of a wheatlike colour ; brown."

9 ધુમવું to plow or ધુમવુ " to linger or hang on ", also "to blow."

10 I do not elearly understand these words which are repeated at the end of every couplet. I submit the following notes.

The word may be madavyâ je ( માડવિયા ન્ ) instead of ( માડરીઆ, ગ્રે. In that case madavi-yo is "a man of the bride's party". (M. B. Belsara's Pronouncing and Etymological Gujarati-English Dictionary (1895) p. 602). So, the meaning would be; "The persons in the bride's party enjoy the fun ( ધुમનુ, to enjoy perfectly). Or probably, the word is માદળિયુ an amulet. The winnowing fans are decorated, and the reference is to the sound made by the decorative articles attached to the winnowing fans. I consulted Mr. Wadia of Nargol on the subject of the meaning of this line and he is not in a position to give any satisfactory explanation.

11 Perhaps from संग्रहणी, disorder i.e. wanderers, loafers.

12 Name of the bride-groom. The author of the song has assumed this name. Other singers may mention the name of a particular bridegroom. 
(3) Sohrelo is at his proper house. He is brought (i.e. won) by. o.... 1 . There move the Madaryas.

4. I brought (from the market) wheat in carts and emptied them on the outside of the steps ${ }^{2}$. There move the Madaryas.

5. The wheat is put into ${ }^{3}$ the winnowing fans. It is...4 It (i.e. the wheat) is then put into round baskets. There move about the Madaryas.

6. The wheat are put into trays and the stony particles are removed. 5 They are then emptied into earthen pots. Madaryas are wandering.

7. My neighbour ${ }^{6}$ began the song of a bell. ${ }^{7}$ I began the song of a hand-mill. The Madaryas are wandering.

8. My neighbour produced (by her grinding) coars? flour 8 and I produced fine wheaten flour. ${ }^{9}$ The Madaryas are wandering.

1 Here the name of the bride is mentioned.

2 ચ્યાસરી "The steps at the entrance of a dwelling house."

3 Sans. सु "to go," "to move."

4 I do not understand this part.

5 The ordinary word is चुंटql i.e. "to pick out (with the hand) stony particles from corn."

6 ૫ડૅસશ is a female neighbour.

7 धं ¿। Bell. The word is not to be taken here in its literal sense, because a bell is never used while grinding corn. What is meant seems to be: "wy neighbour began, while grinding the corn, to sing with a loud (bell-like) voice and I began to sing in a lower tone." We know that in India, ladies generally sing while grinding corn with a hand-mill.

8 ल२รડ? from ભ२૩9ु "to grind coarsely," what seems to have been meant is coarse flour.

9 મેં દેલલા from મેદે| "fine wheaten flour." 